International Journal of Child, Youth and Family Studies (2016) 7(2): 198-217

DOI: $10.18357 /$ ijcyfs 72201615718

\title{
ALTERNATIVE EDUCATION: PROVIDING SUPPORT TO THE DISENFRANCHISED
}

\section{Martin Mills and Glenda McGregor}

\begin{abstract}
This paper is concerned with "what works" in alternative schools, also known as flexible learning centres, in the state of Queensland, Australia. Generally, young people who find their way to an alternative educational provider have left school early due to difficult personal circumstances or significant clashes with schooling authorities and their associated disciplinary requirements. This research at eight case-study alternative schools shows that their students were reconnecting to educational futures because of policies and practices that were quite different from those of mainstream schools. By reimagining their relational, pedagogical, curricular, and pastoral work, many of these alternative schools and centres have created learning environments that cater to the holistic needs of young people, particularly those on the margins of societies. It is our contention that mainstream schools might use ideas from this growing alternative educational sector to inform their practices positively and thus retain many of their most vulnerable students.
\end{abstract}

Keywords: alternative schools, marginalised youth, disengagement

Acknowledgement: Funding for the research from which this article has been developed was provided through an ARC Linkage grant (LP12010014), Marginalised students: Enhancing life choices through engaging educational policies and practices.

Martin Mills, PhD (corresponding author) is a Research Professor in the School of Education, The University of Queensland, Brisbane, Australia 4072. Email: m.mills@uq.edu.au

Glenda McGregor, PhD is a Senior Lecturer in youth studies and history curriculum at the School of Education and Professional Studies, Griffith University, Mt. Gravatt campus, 176 Messines Ridge Rd, Mt. Gravatt, QLD 4122, Australia. Email: g.mcgregor@griffith.edu.au 
International Journal of Child, Youth and Family Studies (2016) 7(2): 198-217

Globally, many governments have shown a commitment to improving school retention rates, addressing disengagement from schooling, and enhancing educational achievement outcomes for all young people (Bush, 2012; Department for Children, Schools and Families [DfCSF], 2007; Evans, Meyer, Pinney, \& Robinson, 2009; Finlay, Sheridan, McKay, \&Nudoz, 2010; Joseph Rowntree Foundation, 2014; Riddell, 2009; Ruiz de Velasco et al., 2008; Scottish Government, 2008). In many Australian jurisdictions alternative educational provision has been central to the project of re-engaging young people who have left the mainstream either through their own volition or through compulsion (Department of Education and Early Childhood Development (Vic), 2010; Harper, Heron, Houghton, O’Donnell, \& Sargent, 2011; KPMG, 2009; Mills, McGregor, \& Muspratt, 2012). Much has been written about the quality, both positive and negative, of this type of provision (Martin \& Brand, 2006; McGregor \& Mills, 2011; Ogg \& Kaill, 2010; te Riele, 2007; Thomson \& Russell, 2007). In this paper, we focus on the current situation in one state in Australia: Queensland. Whilst the States and Territories have Constitutional responsibility for educational matters, in recent times the Commonwealth government has taken a much more interventionist approach through tied-funding regimes (Lingard, 2000; Lingard, Martino, \& Rezai-Rashti, 2013). However, to date, whilst concerned about school retention and achievement, the Commonwealth Government has taken little interest in alternative education provision.

Most Australian states do have approaches designed to address schooling disengagement. For example, in Victoria all government schools are, under its Effective Schools are Engaging Schools framework, expected to develop a student engagement policy ${ }^{1}$. This policy provides support for school-based strategies that include working with community agencies and alternative provision. In all states there are also alternative learning options outside the government system for young people disengaged from school. The Dusseldorp Foundation provides a comprehensive list of these sites (te Riele, 2012). In the Australian Capital Territory (ACT), the Education and Training Directorate worked with a range of agencies serving young people to construct the ACT Youth Commitment, signed in 2011. Its purpose is to determine pathways for re-engagement (see Mills, McGregor, \& Muspratt, 2012 for a discussion of the situation in the ACT). In the state of Western Australia (WA) there is a range of community programs and courses for young people who have left school or who are still in the compulsory phase of learning, but struggling. WA also has a system of independent schools for students with “exceptionally challenging behaviours” called Curriculum and Re-Engagement (CARE) schools (Department of Education [WA], 2014).

In Queensland there has been an expressed concern with disengagement in mainstream schools. Great Teachers =Great Results - A direct action plan for Queensland, is a policy

\footnotetext{
${ }^{1}$ See http://www.education.vic.gov.au/school/principals/participation/Pages/default.aspx
} 
document issued in 2013 by the Department of Education, Training and Employment (Qld) aimed at developing excellence in Queensland's mainstream state schools; it also supports alternative educational provision, demonstrated through funding for what are known as "Special Assistance Schools" (SAS) ${ }^{2}$. These SAS are independent from the government system but supported through government funding. In order to obtain this status they are expected to meet a set of criteria that ensures that highly disadvantaged students receive an education. They are not to charge school fees; they must have flexible and specific accredited educational programs to reengage young people in learning; and they must develop sustainable learning and employment pathways. In addition to the SAS, there is also increasing support from the department for those government schools which have decided to construct alternative education annexes, usually offsite, to support young people who appear to have rejected, or been rejected by, mainstream schools.

In this paper we explore an SAS and an annex model of alternative provision. Our focus on these two schools is based on the grounds that they appear to be making a significant difference to the lives of their students and, we suggest, offer lessons to both the mainstream and alternative education sectors. We are concerned with three key elements: the material supports they provide to students; their climate; and their pedagogy and curriculum. Material supports are essential to ensure that many of the barriers that prevent these students from attending school are, if not removed, somewhat disrupted; the climate is also essential in that the climate of previous schools is what has been at the heart of many students' exit from the mainstream; and pedagogy and curriculum, we argue, has to be a key concern to ensure that these schools become something other than drop-in centres and are able to provide students with a meaningful education.

In order to provide a quality education to all young people it is vital that alternative provision is viewed as "different from" not "inferior to" mainstream education. There has been growing recognition of the importance of a rigorous curriculum as opposed to a narrow focus on competencies and skills in the field of curriculum theory (Biesta, 2006, 2014; Yates, 2011; Young, 2008;). Biesta (2014) reminds us of John Dewey's (1895) point that “the problem of education lies in the co-ordination of the individual and the social factors". His work is interesting in that it indicates the need for pedagogy and curriculum to be more than childcentred; drawing on Dewey's theories, he argues that the approach should be "communicationcentred ... and ... that education is neither about getting the curriculum into the child nor about the child doing just anything, but about establishing a productive and meaningful connection between the two" (Biesta, 2014, p. 30). Hence, when considering the curriculum offered in alternative schools, centres, and programs, consideration must be given to what is offered (depth, breadth, disciplinary knowledge, and skills); why it is offered (pathways and futures); and,

${ }^{2}$ See http://education.qld.gov.au/schools/grants/non-state/recurrent.html 
International Journal of Child, Youth and Family Studies (2016) 7(2): 198-217

DOI: $10.18357 /$ ijcyfs 72201615718

equally importantly, how it is taught: pedagogy is as important as content and disciplinary knowledge if young people are to be engaged in education. Additionally, if we accept current curricular thinking, the communicative context of students and teachers (i.e., relationships) must be included as a significant element. Thus, within our case-study sites, the relational environment was fundamental to facilitating effective pedagogy and subsequently, meaningful learning experiences for the students.

\section{The Study and Method}

The data for this paper are drawn from a larger study of alternative educational provision in Queensland which began in 2009 and grew with available funding to continue into 2015, involving eight case-study schools located in diverse regions of the state. For much of the research we collaborated with the peak body, or advocacy group, for youth workers in the state, the Youth Affairs Network of Queensland (YANQ). All relevant ethics approvals were obtained, and pseudonyms have been used for all participants and schools. The research sought to provide in-depth analysis of the types of practices that re-engage young people in learning.

In gathering data we utilised a mixed methods approach. Thirteen telephone surveys (3060 minutes) and sixteen on-line surveys were undertaken with key personnel from the youth sector, and Queensland Youth Services in rural and regional areas of the state. These surveys helped to map existing alternative educational providers and determine awareness of such services among professionals who work closely with disadvantaged and marginalised young people. Paper surveys were undertaken with the following groups in urban, rural, and regional areas of Queensland:

- 79 workers (teachers and youth support) in 13 alternative education sites, to determine how referral processes work and to ascertain their views on the types of programs and practices that are the most effective in terms of retaining and challenging the young people;

- 154 young people undertaking education in 15 flexible education sites and programs, to determine the factors that attracted them to the sites, the practices and learning occurring at the sites that they found useful, and their aspirations for the future;

- 36 young people who had disengaged from all formal educational processes, to explore their knowledge of alternative education services in their local region, their broad aspirations for further study or employment, their experiences of education, and their recommendations for alternative sites.

The young people asked to complete this survey were approached through a variety of agencies that have contact with young disengaged people (e.g., youth legal services, housing and accommodation service providers). 
International Journal of Child, Youth and Family Studies (2016) 7(2): 198-217

DOI: $10.18357 /$ ijcyfs 72201615718

From the alternative education sites that participated in the relevant surveys, eight casestudy sites were selected to supplement and enrich the initial data. These sites all provide educational opportunities for young people who have disengaged from education. They were selected to exemplify different approaches to alternative educational provision. There was also diversity in: location (e.g., inner city, regional, rural, remote); in the characteristics of the young people catered for (e.g., Indigenous young people, pregnant girls and young mothers); in the types of programs offered; and in governance and funding. The aim was not to obtain a representative sample across all these variables but to identify schools that exemplify different ways of re-engaging young people in varying circumstances. Visits were conducted periodically during the course of the project.

Data collection methods included on-site observations and analyses of documents. All such preliminary data helped to inform the subsequent interviews at our case-study sites with 68 administrators, workers, teachers, and community volunteers; and 81 young people. These semistructured interviews aimed to explore participants’ personal experiences as well as their perspectives on their particular site and its practices. For purposes of this paper, two case studies were chosen to reflect two particular models of alternative schooling in Queensland. Our first case study, Victoria Meadows Learning Centre, has been selected from the Queensland Government's list of Special Assistance Schools; and the second, Woodlands Flexi-school, from the high school annex models in our study.

As well as being an SAS school, Victoria Meadows Learning Centre is also part of a youth program sponsored by a major church, which has become increasingly involved in the Australian alternative education sector, operating 17 flexible learning centres nationally, 12 of which are situated in Queensland. According to its website, this network "celebrates the unique character and hopes of young people of secondary school age and is dedicated to "enfranchising young people through inclusive learning communities”. These centres, which are registered schools, focus on re-engaging young people in educational pathways within contexts of "trusting relationships”. All their flexible learning centres focus on the individual needs of young people; small group learning; teacher and youth worker support; learning experiences supporting social and emotional needs of young people as well as academic skills; and empowering young people to take personal responsibility for their actions and learning.

Complementing this educational framework are four principles: "Respect, Participation, Safe \& Legal, and Honesty”. According to their website, these principles are used by young people and staff to encourage learning, build personal relationships, and resolve conflict. Whilst our focus here is on Victoria Meadows, and not the actual youth program sponsored by this church, it should be noted that we have visited many sites within this network and despite the structural similarities, each flexible learning centre in the network has unique characteristics and ways of operating because the needs of their students are shaped by their local contexts, geographies, and histories. 
International Journal of Child, Youth and Family Studies (2016) 7(2): 198-217

DOI: $10.18357 /$ ijcyfs 72201615718

The off-site high school annex model operating in Queensland provides an alternative school for those young people whose needs have not been met by mainstream educational contexts. This model requires mainstream state schools to retain responsibility for all their students rather than seeking to remove those who prove challenging in terms of behaviour and educational engagement. Woodlands Flexi-school is attached to a state high school, and along with their "parent-school" students, it also takes students from other high schools in the town. In our various discussions with senior people in the state department of education in Queensland, it was very apparent that this school is seen by many within the bureaucracy as one of its flagship alternative schools.

\section{Victoria Meadows Flexible Learning Centre}

Victoria Meadows Flexible Learning Centre was founded in 1990 for homeless young people by a major City Council in a central city park. In 2000 it moved to a building in an inner city neighbourhood. In 2004 it once more relocated, this time to its current location in shared premises with a behavioural management unit, again very close to the Central Business District. In 2006 it became a registered school. Historically, Victoria Meadows Flexible Learning Centre has mostly catered to young people in the post-compulsory years of education. Many of these young people have had to contend with homelessness, early parenthood, mental illness, and various forms of addiction. Being in the post-compulsory age group has meant that attendance has traditionally been entirely voluntary and their re-engagement with education as flexible as their lives allow.We were told that, due to increased demand, the school was in the process of opening up to younger students.

Our research involvement in Victoria Meadows Flexible Learning Centre started in 2009. Since that time, we have spoken to a students, teachers, workers, and several campus coordinators. The essential story remains constant: this is a school that is making a great difference in the lives of many young people who are not only struggling to re-engage with educational institutions but are also seeking solutions to many personal challenges in their lives. Thus, this school prides itself on being known as a "learning community" with the following characteristics: it is a non-uniform school; first names are used for all people regardless of age and position; teachers, youth workers, and other support staff are usually known simply as "workers"; the staff's work crosses boundaries of teaching and counselling regardless of their formal titles. Young people who attend Victoria Meadows come from a range of ethnic backgrounds, although white working-class Australian students are in the majority, and many are living independently. The centre also caters to young parents, primarily young mothers. Evidence from our research at this site clearly supports the perspective that broader socioeconomic factors along with a variety of social prejudices are major contributors to young people’s disengagement from mainstream schooling. One girl, who had a small child but very little support, felt forced out of her previous school: 
International Journal of Child, Youth and Family Studies (2016) 7(2): 198-217

DOI: $10.18357 /$ ijcyfs 72201615718

My mum left to go to Sydney when my daughter was four months old - and my dad's never met my kids so ... yeah, I moved into my boyfriend's house and his mum and dad supported me - and then yeah he’s left. The principal (of former school) just basically told me halfway during the year "leave or I'm just going to fail you and expel you at the end of the year”. And yeah, I just left. (Sarah, Victoria Meadows)

While the backgrounds of the students were diverse, common elements include strong life ambitions and determination. To maintain their connection to learning, some juggle work and/or caring responsibilities, while others travel significant distances . During an interview with one young student it emerged that her daily trip to the flexible learning centre took 90 minutes. On the way to school she passed several mainstream schools, the closest of which was just a five minute walk from her home.

At the time of this research, Victoria Meadows was operating as a senior campus. As mentioned earlier, this was to change in 2015; however, they intended to maintain their approach to education, which a social worker told us was "informed by adult education models", and where attendance at the school had to be voluntary. She noted that, "we can’t operate with young people who... are mandated to come”. Many of the young people at Victoria Meadows had been suspended or excluded for a variety of reasons from mainstream schools. They tended to look back at their times in those schools with anger, resentment, or sadness. Yet, in this school, they spoke of the respect they had for the workers and for the school and what it was trying to do for them. Much of this respect came from the ways in which they were given opportunities to make contributions to the community and to the ways in which they were listened to by the workers. Flexible arrangements for attendance and completion of tasks for learning underpin the ways in which Victoria Meadows accommodates the many challenges inherent in the lives of the students. Their focus is on retaining students and this may mean allowing the students to have periodic sessions of non-attendance while they sort out their lives. The metrics that apply in mainstream settings would not work here.

\section{Material Support for Students}

Victoria Meadows Flexible Learning Centre tackles head-on the lack of resources and poverty that face many of its students. For instance, there is a crèche so that young parents, primarily young women, are able to access childcare while they are studying. According to one young mother:

Because I can still have my education, my son can come and it's, like, I don't know, it's so much different to a school like you have a really good relationship and bond with the teachers and other students. No one looks at you differently, everyone gets along ...

Throughout the day, provision is made for such things as food, showers, and access to social workers who can locate shelters for those needing accommodation or access to legal 
International Journal of Child, Youth and Family Studies (2016) 7(2): 198-217

DOI: $10.18357 /$ ijcyfs 72201615718

services. Meeting the material needs of these young people was critical for ensuring that they could stay at school. However, this alone did not completely explain many of the young people's ongoing commitment to their education. There were other elements identified by the students, including: the environment; teaching strategies; relationships; and curricula that were connected and relevant to the interests and goals of students.

\section{School Climate: Environmental and Relational Factors}

The way people treat each other impacts the emotional climate of places and this was frequently noted by our interviewees. Like the other schools in this youth network, Victoria Meadows Flexible Learning Centre has replaced traditional school rules with the Four Rs "Rights, Respect, Relationships, and Responsibilities". These apply to staff and students alike. One of the teachers affirmed the need for having: "A place where difference is accepted, where alternative viewpoints are accepted; alternative lifestyles are accepted in a safe and respectful environment where your ability to succeed in academic endeavours isn't the be all and end all of you as a person.” Another teacher stressed the importance of community in contrast to some structures he had experienced in mainstream schools: "One of the advantages that Victoria Meadows has is that it started with community and has introduced education rather than beginning with education and introducing community." He believed that this was fundamental to the creation of a "learning community".

Teacher/youth worker Gary noted the relationship-focus of the school: "To me, schooling and stuff is about relationships - we work within principles, not rules - those principles of 'respect, relationship, safety, rights and responsibilities'...” The positive relationships and community ethos were also noted by a female student who had come to Victoria Meadows after suffering severe bullying at her previous school: "[Our] community is a really big thing. It is really nice because if I am having problems, I am not afraid to talk to any of the teachers.” The use of first names as an important aspect of the emotional climate of the school was noted by many students. It also worked to distance many of the students from their earlier negative experiences of schooling. One of the students explained:

You know it's not Sir, Madam, it's not Mr. and Mrs. Whatever. I couldn't even tell you what half the teachers' last names were.... Yeah pretty much, they're all you know, like, George or Angela and .... It makes you feel equal, not below, like it's not "Yes sir, no sir, three bags full sir".

This student who had had a very difficult time at his previous school was fully engaged in learning and he saw the practices that "make you feel equal not below" as central to supporting this engagement. Given the stressful issues many of the young people face, students are sometimes asked to go home as a "circuit breaker" when emotions run high, however, they are always welcomed back. Workers and students at the school emphasised to us that their 
International Journal of Child, Youth and Family Studies (2016) 7(2): 198-217

DOI: $10.18357 /$ ijcyfs 72201615718

relationships were based on trust and that when students were asked to take some time out they later returned to the school and the issue was addressed as a community.

In sum, the environment cultivated at Victoria Meadows aims to be a socially supportive and educative one that allows young people to develop interpersonal skills that facilitate their relationships elsewhere, as noted here by the Associate Head of Campus, Damian:

Just to be able to sit down and have lunch with other young people and adults; to be able to pick up their plate and put it away and not be engaging in any social aggressive behaviour and just to be able to interact; where we are working with young people and they are able to develop these life skills and be able to be members of the community; and be able to then get work/jobs, because they are now able to socialise and interact.

\section{Pedagogy and Curriculum}

Students at Victoria Meadows have learning plans that responded to individual needs. If there is a need to address learning gaps, the focus will be on those areas; teaching begins at the place where each student is at. The young people who attend Victoria Meadows work at their own pace along curricular pathways that may lead to the Queensland Certificate of Education ${ }^{3}$ or a variety of Technical and Further Education (TAFE) Certificates, preparation for university studies, or employment. Students appreciated the individualised instruction and pathways as noted by this student, Craig, "The teachers are willing to help you out and have one-on-one sessions if required and they treat you like an actual person, no matter what your back story.”

Structures at the school are also flexible enough to allow young people to manage their lives as well as their learning as noted here by one of the students, Keith:

Like, it's flexible - you'll have assignments but like, people might have things going on at home, and in a normal school they wouldn't take that into consideration whereas here they'll take that into consideration, like personal things. There's reasons you can't do your assignments.

Material support coupled with supportive, respectful relationships shape the pedagogy and flexibly delivered curriculum, as evidenced in this story from a 20-year-old man who had come to Victoria Meadows to finish Year 12 and had found support for his musical ambitions there. The staff were going to accompany him to the nearby college of music technology:

\footnotetext{
${ }^{3}$ The QCE is Queensland's senior school qualification, which is awarded to eligible students usually at the end of Year 12. The QCE recognises broad learning options and offers flexibility in what, where, and when learning occurs.
} 
International Journal of Child, Youth and Family Studies (2016) 7(2): 198-217

DOI: $10.18357 /$ ijcyfs 72201615718

Well, Olivia (music teacher) has been trying to talk to them and see if we can go in for a visit one day and just talk to them about it, see what we actually need to be able to get in, if that's what we want.

He described how another student had been able to get a job through a similar process:

The other month we had Ronald (worker) take a couple of us over to The Wharf [a nearby music studio] and we did the induction there. After that, one of the guys actually got a job at The Wharf ...

Many of the young people who attend Victoria Meadows Flexible Learning Centre face challenging life issues. However, what was very apparent in the comments from our student participants was that the vast majority of these students would not be in any form of education at all if it were not for the opportunities provided by Victoria Meadows. This school provides a way for young people to reconnect educationally within a supportive environment that includes real material assistance with childcare, accommodation, food and clothing, and various types of help in accessing social security and legal support.

\section{Woodlands Flexi-school}

Located in a regional city of Queensland, Woodlands Flexi-school began as a community project involving a regional university education academic, a member of the local council, and a school counsellor. It was originally set up in the mid-1990s as a drop-in centre where homeless or disadvantaged young people could come and talk to volunteers. Many of these young people indicated interest in returning to school so the centre organised distance education for them. This, one of the founding members indicated, "worked well for a few years”. However, he noted that there was a sense of something missing. As the president of a community organisation, Rotary, in the town, in 2001 he worked with the local business community and the city council, which between them donated buildings and land, to set up a school for these students. In 2005 they approached a local high school that had a very supportive principal to take over the responsibility for the school; she was able to garner support from the state department of education and has remained as the principal of the school, with staff from her mainstream school, including the teacher-in-charge, allocated to the Flexi-school. The latter has Community Partnerships with many local groups including a local men's network and the local university. In 2010, its sponsor high school won the Queensland Multicultural Service Award in Education and the National Australia Bank Schools First “Local Impact” award for the work it was doing with the Flexischool in respect of disadvantaged young people and creating inclusive learning pathways.

As with Victoria Meadows, we have had a connection with the school since 2009. Many of the staff have remained the same, including the principal of the sponsor school and the head of campus, along with board members and community support. Whilst the students have changed, their issues have remained relatively constant. Many students came from very difficult family 
International Journal of Child, Youth and Family Studies (2016) 7(2): 198-217

DOI: $10.18357 /$ ijcyfs 72201615718

circumstances and some were living independently. Shona, one of the teachers, also told us: "So we get quite a few kids who are maybe under a psychologist's care, on medication, have had a history of ... types of mental illness, like depression, anxiety, all of that.” She went on to say:

The majority of kids - my Year 10s from last year, probably 90 per cent of them were victims of the bad elements of other schools and they were so highly anxious or bullied or whatever, they came in here and went, "Ohhhh, we can learn. ” I had the best time with my Year 10s last year; they were just beautiful.

The school has a waiting list and tries to support those in most need. The head of campus, Judy, indicated that they gave priority to those who had very little support at home:

When a child doesn't have anyone to build those relationships with and they are disengaging and they are depressed and anxious, that's when they need a centre like this that basically becomes their family, becomes their support; they build self-confidence, self-esteem and then they can get themselves on the right track.

The principal of the main school, Margaret, also remarked: "We are well aware of our growing waiting list over time and we are also well aware of the increasing (demand)... at a far younger age." She noted that many of her colleagues in primary schools were finding the demands of student needs greater and greater. She went on to say: "So they are struggling in primary schools and then we pick this up in Year 8, and of course, too young, too young for flexi."

\section{Material support for students}

An important aspect of Woodlands Flexi is the material support it provides to students, including clothing, transport, and access to social security and legal aid. Some of it is quite simple, like the provision of food:

Children know they can come and have brekky and smell cookies baking. It is a homely smell — one of our basic needs. So they feel like, “Okay, if I go there, someone's going to chat to me, someone's going to feed me. ” While they are here, “okay, here's an English class”!

The school also helps students in quite substantial ways. One Indigenous girl aged 16 who had had a very difficult life — her mother was in gaol and she lived with her grandmother who had a brain tumour — told a story about how she had made a decision to return to education after dropping out, and about how the school had helped her pursue her love of dance: "I explained to her [the principal], 'I love dance. My goal is to get to Bangarra.' " She went on to say how the staff had managed to organise work experience for her with Bangarra, and how they had kept the organisation of the trip secret from her and that when they did tell her: 
International Journal of Child, Youth and Family Studies (2016) 7(2): 198-217

DOI: $10.18357 /$ ijcyfs 72201615718

I nearly cried when I found out because, yeah, since — it's a pretty big thing.... and I just thought, “I'm so happy that I came back because it's just helped me so much”, like in the past couple of months I have gotten so far and got my head screwed on, that I definitely want to go somewhere. If I was in any other school, I would still be like, “Oh”, you know, having doubts about it.

Using funds from the account set up with prize money from one of the school's national awards, two of the teachers from the school took her to Sydney for a week to work with Bangarra as part of her work experience. At the time of our last visit, she had an application in to a Bangarra feeder dance school in NSW for the end of year 12. She went on to say how much she loved the school and how it was "like a family environment" and how a lot of the students came up to her to say: "Good luck. I hope you have fun”.

\section{School Climate: Environmental and Relational Factors}

The workers and teachers at Woodlands strive to ensure that there is a positive climate and relationships in the school. However, the head of campus was at pains to tell us that this is something that should come quite easily. She spoke of how the students feel when they come to school:

They are happy. They are really happy. People think that it can’t be that simple but it is that simple! People often ask me, "What do you do?" We do nothing special. We do basic things. We do them well, but they are basic; basic, basic. You know, feeding someone; talking to someone; making a connection; asking them about their day; they are basic, basic things. It's finding the right people who care, who take that time to find a staff, and then just building the warmth around it and then they want to come.

Central to creating a positive climate in the school is the linking of students with adults with whom students can build a connection. The head of campus told us:

You want some significant person in their life to take an interest. That could be a mentor, it could be a connection with a teacher, it could be an employer.... Sometimes it can be someone quite random ... that makes the difference.... We link with community, Rotary, employers. A lot of employers, amazingly, take our students under their wing, and they just see something special.

The school's mentoring system with a local men's organisation is run by the "outreach officer”, Mary. She organises the mentoring and is responsible for Indigenous engagement and has a key role in the school. The head of campus noted the significance of her work:

And those support people are really important. It gives children a different face to talk to. That I love, because not everybody is going to connect to the one person. You have got lots of personalities around, lots of options. 
International Journal of Child, Youth and Family Studies (2016) 7(2): 198-217

DOI: $10.18357 /$ ijcyfs 72201615718

We were also told that the environment is supportive enough that students who are gay or lesbian are able to be "out". The head of campus informed us that bullying of any form of difference was not tolerated:

We are quite hard on bullying here and basically just, yeah, I get students to talk about it immediately, whatever is said. You know, they are encouraged to write it down ... we can't have it. It wouldn't be any good for the students that are here.

All the students we spoke with praised the teaching. One boy in Year 11, Corey, had been referred to the Flexi-school after he had started failing at school and had "got to the point where I just didn’t care anymore”. He wanted us to know how good the school and the teachers were:

It's great, it really is ... I think it is not just the one-on-one with the teachers, but more that — not that it is lenient — it is better because the teachers are nicer ... they are allowed to be themselves. They don't have to put on a face or mask and act.... They can tell you to be quiet like a normal person. They can talk to us normally. It's great.

He was now hoping to go to university to do science: "I really love science. It's one of my biggest passions. Always talking about it, facts, information, everything. I enjoy space, chemistry, physics, everything."

This did not mean that there are never any tensions at the school. This same boy, Corey, also described an incident after some students had been "mucking up" in maths and the teacher had said to the head of campus that they "had lost the meaning of flexi-school" which had "crushed her". Following this she ran an "hour-long session” with the students, "talking about what flexi was and why we were here.”

\section{Pedagogy and Curriculum}

Woodlands Flexi was focussed on providing the students with a rich and rigorous curriculum. However, the quality of the environment was seen as being central to engaging the students. The head of campus, Judy, explained: "First of all, before we even went to the curriculum, we wanted to make this place a place where they feel welcomed and they feel connected. Because once you build that relationship, they will do anything for you. Then you build the curriculum.” This, she argued, required high-quality teachers: “If a teacher can't cut it in mainstream, they are not going to cut it here." As a consequence the teachers were handpicked from the main high school. The people they looked for were those who related well to young people, but were also experienced. The head of campus emphasised this:

I believe you have to start in mainstream. You have to build your skill, build your craft, and this is something ... you do have to have good content knowledge, too, because you have got children from such a wide range. So you don't want to get teachers who are struggling with the content in mainstream... Yeah, you do want good teachers. 
International Journal of Child, Youth and Family Studies (2016) 7(2): 198-217

DOI: $10.18357 /$ ijcyfs 72201615718

From our observations, they appeared to have found such teachers. We examined some of the work and listened to students in one class as part of this study and were impressed with the quality of work that the students were undertaking. For example, Shona, who taught English, Study of Society and the Environment (SOSE), and Art at the school, has a double major and honours in English and a thorough understanding of effective pedagogies. She taught a lot of integrated units, sought to ensure that there was relevance in the unit, and often provided opportunities for students to present their work publicly. At the time of one visit the Year 10s were doing a poetry unit where they had to analyse three poems and create one of their own; they would then represent the theme or mood of their poem in an artwork. Their work was to be used in the school magazine at the end of the year. Shona showed us some of the work associated with this unit, commenting, “They do a whole heap of things that they don't realise ... We look at gaps and silences and discourse.... we use those terms. They don't realise that they are actually doing it."

The students here were involved in work of a high intellectual quality. However, at the same time Shona saw a place for rote learning in order for the students to obtain some facts. For instance they had been doing a unit on World War 1 in SOSE. She said that they had had to do a lot of rote learning for them to grasp some of the key events and she did some short-answer closed questions at the beginning of each lesson to reinforce this learning. Once the students were able to answer some of the factual questions, she said, "They were so excited.... And they started asking each other questions, 'Would we change sides?' For the first time in their lives, they know what's going on.” She was also able to link this to current events for them to see the relevance:

The kids were actually interested in what's happening in Russia and Ukraine. Now, again, it's a perfect thing to actually say, "Well, here's the history of your Balkan States in World War I. You can see the problem still exists.” So it’s linking the current knowledge in that as well.

Importantly, as evidenced by the quality of her lessons as well as her attitudes, Shona had also rejected deficit constructions of the students:

What I keep saying to these kids is "You are not stupid. You just haven’t been taught or you haven't got the skill or you don't know the rule.” ... I don't tend to treat the kids down here intellectually any differently, while we modify a whole heap of other things.

This rejection of negative constructions of the young people was also reflected in other teachers' comments. Mary, another teacher, for example, stressed to us the significance of students' efforts in just attending school:

Some of these kids are coming from fairly horrific backgrounds/families and they are getting themselves to school ... We don't recognise the individual backgrounds of these 
International Journal of Child, Youth and Family Studies (2016) 7(2): 198-217

DOI: $10.18357 /$ ijcyfs 72201615718

kids. We don't give them any credit for the fact that they even get up and come to school, in their circumstances.

In summary, Woodlands has developed a very positive reputation within the state department of education and the local community. It caters to some of the most highly disenfranchised young people in the local area. It supports students not only from its own sponsor school, but also many other schools in the local area. Many of the independent schools in our study are isolated and receive very little support, apart from some funding from the Department of Education, Training, and Employment if they have managed to acquire SAS status, although Victoria Meadows benefits from being part of the youth network. However, for Woodlands Flexi-school there were obvious benefits to being attached to a high school. Being connected to the main school ensures, for instance, that teachers have access to professional development, and, as noted by the principal, "All professional learning is shared; all structures are shared”. This sharing was critical to the Flexi-school's success. Margaret noted that the high school subsidised the nurse, social worker, and guidance officer at the Flexi-school. However, the head of campus believed that being physically separated from the main school site was also central to the way in which the students engaged with the Flexi-school. She told us:

I think they feel more special because it's their little place. ... We tell them, “This is a great place to be.” We have our own graduation day. We have our own formal. They love it. We make a big deal of it.

\section{Analysis and Conclusion}

These two case-study schools highlight a number of key features about alternative schooling. They provide a snapshot of the types of issues that are faced by young people that lead to their departure from the mainstream. These issues relate to the lack of economic and material assistance they have in their lives, and the consequences of that for their engagement with conventional schools that usually lack the wrap-around services required to support young people in need. The case studies also give some indication of the ways in which the climates in their previous schools impacted upon their sense of being valued and how this was also a key feature in their exit from the mainstream. The case studies show that most of the young people who leave the mainstream are still interested in learning. These two schools were both highly successful in engaging young people and providing them with opportunities to demonstrate this.

The material supports that the schools provide to students are not simply drawn from their own budgets, but include the backing from and engagement with other organisations. As with many of the alternative providers in our research, these schools alluded to their close working relationships with their local communities, which provide access to elements fundamental to helping young people re-engage with education, training, or employment. These include access to health and welfare agencies, both government and private; social security, accommodation, and youth services; and supportive relationships with organisations such as 
International Journal of Child, Youth and Family Studies (2016) 7(2): 198-217

DOI: $10.18357 /$ ijcyfs 72201615718

Rotary, town councils, and business groups so as to facilitate support for fund-raising; building projects; mentoring of young people; and opportunities for work experience and possibly apprenticeships. The schools are smaller than typical mainstream schools, which facilitates the development of a positive climate where students and teachers have opportunities to get to know each other. It also provides possibilities for students to express their concerns and to ensure that their voices are heard. Many students noted that the small size of their school meant that they could express their differences in an environment where they felt respected and supported.

In terms of the learning that was taking place in the alternative sites, we noted that as the nurturing environments shaped positive self-esteem for the young people, students increasingly expressed a growing confidence in their ability to learn. Such confidence translated into expressed feelings of greater enjoyment of learning and shaped their belief in the possibility of preferred futures. Teachers adopted individualised approaches to assessing the starting point for each young person and then developed learning plans that took into account the interests and aptitudes of each student. They asked them what they wanted to be and then helped them find ways to begin their journeys towards such goals; the story of the young aspiring Bangarra dancer is but one example of this approach.

Most of these schools do not take part in regimes of national testing such as the National Assessment Program - Literacy and Numeracy ${ }^{4}$ (NAPLAN) and at present, hard data in respect of specific academic outcomes are patchy. More research that tracks students longitudinally is needed to provide this, but we have much qualitative evidence to support our contention that these alternative schools are facilitating meaningful learning for students that can lead to employment and/or further education. It is not always possible to quantify the learning that occurs in schools and we would argue that for the young people who use alternative sites, the evidence of "outcomes" is manifest in their greater self-efficacy and developed capacities relevant to the pathways they choose post-school.

In this paper we have demonstrated some of the ways in which two alternative schools in the Australian State of Queensland have sought to make a difference to those young people who have exited the mainstream sector, either of their own accord or due to pressure from their former schools, which failed to acknowledge and accommodate difficult personal circumstances. In providing these two case studies, we are not suggesting that they offer a "recipe for success" but rather that they provide a snapshot of some of the current practices that appear to be making a difference in the lives of previously disengaged young people. Asking these young people what they might be doing without their alternative school drew responses such as "nothing”, “crime”, "dead", and "drugs". Attending these schools had changed their lives. However, we have discovered that a number of jurisdictions (some European countries, for example) emphasise the importance of changing the mainstream rather than providing alternative provision (Harper et al.,

${ }^{4}$ http://www.nap.edu.au/naplan/naplan.html 
International Journal of Child, Youth and Family Studies (2016) 7(2): 198-217

DOI: $10.18357 /$ ijcyfs 72201615718

2011). They argue that having a second tier of educational options enables mainstream schools to abrogate their responsibilities to all students and can lead to increased referrals from the mainstream. We have some sympathy for this argument. We too are of the view that the mainstream needs to change to better meet the needs of young people they are currently failing. A former youth worker, and now principal, in one of the alternative schools in our larger project, told us that the existence of their school was "like the canary in the mine" — it proved that the mainstream system was not working. We would suggest that there is, therefore, much that the mainstream sector may learn from the most effective of these alternative schools in order to cater to the educational needs of all young people. 
International Journal of Child, Youth and Family Studies (2016) 7(2): 198-217

DOI: $10.18357 /$ ijcyfs72201615718

\section{References}

Biesta, G. (2006). “Of all affairs, communication is the most wonderful.” Education as communicative praxis. In D. T. Hansen (Ed.), John Dewey and our educational prospect: A critical engagement with Dewey's democracy and education (pp. 23-37). Albany, NY: SUNY Press.

Biesta, G. (2014). Pragmatising the curriculum: Bringing knowledge back into the curriculum conversation, but via pragmatism. The Curriculum Journal, 25(1), 29-49. doi:10.1080/09585176.2013.874954Bush, S. (2012). Building effective learning environments in California's continuation high schools (Issues brief). Stanford, CA: John Gardner Center.

Department for Children, Schools and Families (DfCSF). (2007). Raising expectations: Staying in education and training post-16. Norwich, UK: The Stationery Office.

Department of Education (WA). (2014). Department of Education Annual Report 2013-2014. Perth, Australia: WA Government. http://www.education.wa.edu.au/home/detcms/publiceducation/content/about-us/publications/annual-reports/2012-2014/department-ofeducation-annual-report-2013-2014.en?cat-id=14662810

Department of Education and Early Childhood Development (Vic). (2010). Pathways to reengagement through flexible learning options: A policy direction for consultation. Melbourne, Australia: Student Wellbeing Division. http://www.education.vic.gov.au/Documents/school/principals/participation/reengagepathw ays.pdf.

Department of Education, Training and Employment (Qld). (2013). Great teachers = Great results. Brisbane, Australia: Queensland Government. http://education.qld.gov.au/schools/grants/state/previous-funded-programs/greatteachers.html

Dewey, J. (1895). Plan of organization of the university primary school. In J. A. Boydston (Ed.), The early works (1882-1898) [Vol. 5, pp. 96-109]. Carbondale and Edwardsville, IL: Southern Illinois University Press.

Evans, J., Meyer, D., Pinney, A., \& Robinson, B. (2009). Second chances: Re-engaging young people in education and training. Essex, UK: Barnardo’s.

Finlay, I., Sheridan, M., McKay, J., \& Nudzor, H. (2010). Young people on the margins: In need of more choices and more chances in twenty-first century Scotland. British Educational Research Journal, 36(5), 851-867. doi:10.1080/01411920903168532 
International Journal of Child, Youth and Family Studies (2016) 7(2): 198-217

DOI: $10.18357 /$ ijcyfs 72201615718

Harper, A., Heron, M., Houghton, E., O’Donnell, S., \& Sargent, C. (2011). International evidence on alternative provision (INCA Thematic Probe). Slough, UK: NFER.

Joseph Rowntree Foundation. (2014). Young people in Scotland not in education, employment or training (NEET) by local authority. York, UK: Author. http://data.jrf.org.uk/data/NEETSscotland-la/

KPMG. (2009). Re-engaging our kids: A framework for education provision to children and young people at risk of disengaging or disengaged from school. Melbourne, Australia: Author.

Lingard, B. (2000). Federalism in schooling since the Karmel Report (1973): From modernist hope to postmodernist performativity. The Australian Educational Researcher, 27(2), 2561.

Lingard, B., Martino, W., \& Rezai-Rashti, G. (2013) Testing regimes, accountabilities and education policy: Commensurate global and national developments. Journal of Education Policy, 28(5), 539-556. doi:10.1080/02680939.2013.820042

Martin, N., \& Brand, B. (2006). Federal, state, and local roles supporting alternative education. Washington, DC: American Youth Policy Forum.

McGregor, G., \& Mills, M. (2011). Alternative education sites and marginalised young people: 'I wish there were more schools like this one’. International Journal of Inclusive Education, 16(8), 843-862. doi:10.1080/13603116.2010.529467

Mills, M., McGregor, G., \& Muspratt, S. (2012). Flexible learning options/centres in the ACT [Report]. Canberra, Australia: ACT Government Printer.

Ogg, T., \& Kaill, E. (2010) A new secret garden? Alternative provision, exclusion and children's rights. London, UK: Civitas.

Riddell, S. (2009). Social justice, equality and inclusion in Scottish education. Discourse: Studies in the Cultural Politics of Education, 30(3), 283-296. doi:10.1080/01596300903036889

Ruiz de Velasco, J., Austin, G., Dixon, D., Johnson, J., McLaughlin, M., \& Perez, L. (2008). Alternative Education Options: A Descriptive Study of California Continuation High Schools( Issues brief). Stanford, CA: John Gardner Center.

Scottish Government. (2008). Closing the opportunity gap: Anti-poverty framework. Edinburgh, Scotland: Scottish Executive.

te Riele, K. (2007). Educational alternatives for marginalised youth. Australian Educational Researcher, 34(3), 53-68. 
International Journal of Child, Youth and Family Studies (2016) 7(2): 198-217

DOI: $10.18357 /$ ijcyfs 72201615718

te Riele, K. (2012). Learning choices: A map for the future. Melbourne, Australia: Dusseldorp Skills Forum.

Thomson, P., \& Russell, L. (2007). Mapping the alternatives to permanent exclusion. York, UK: Joseph Rowntree Foundation.

Yates, L., \& Grumet, M. (Eds.). (2011). Curriculum in today's world: Configuring knowledge, identities, work and politics. London, UK: Routledge.

Young, M. (2008). Bringing knowledge back in: From social constructivism to social realism in the sociology of education. London, UK: Routledge. 